\title{
MATRIK
}

Jurnal Manajemen dan Teknik Industri-Produksi

Journal homepage: http://www.journal.umg.ac.id/index.php/matriks

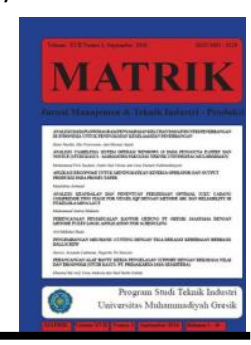

\section{Perancangan Desain Mesin Produksi Otak-Otak Bandeng Dengan Metode Quality Function Deployment} Muharom $^{1^{*}}$, Astria Hindratmo ${ }^{2}$

${ }^{\left({ }^{*}\right)}$ Program Studi Teknik Mesin, Fakultas Teknik, Universitas Wijaya Putra Surabaya

${ }^{(2 *)}$ Program Studi Teknik Industri, Fakultas Teknik, Universitas Wijaya Putra Surabaya

Jl. Raya Benowo no. 1-3, Surabaya, Jawa Timur, Indonesia

muharom@uwp.ac.id

\section{INFO ARTIKEL}

doi: $10.350587 /$ Matrik v18i2.589

\section{Jejak Artikel : \\ Upload artikel \\ 23 April 2020 \\ Revisi oleh reviewer \\ 15 September 2020 \\ Publish \\ 16 September 2020}

\section{Kata Kunci :}

Usaha Kecil Menengah,

Teknologi Tepat Guna,

Quality Function

Deployment,

House Of Quality
ABSTRAK

Jumlah UKM di Indonesia semakin tahun mengalami

perkembangan, akan tetapi banyak UKM memiliki beberapa permasalahan yaitu sulitnya meningkatkan jumlah produksi yang dikarenakan banyak UKM belum menerapkan teknologi tepat guna (TTG). Hal tersebut mengakibatkan waktu produksi cukup lama dan biaya produksi menjadi mahal. UKM otak-otak Bandeng di daerah Gresik saat ini sebagian besar masih memproduksi otak-otak Bandeng secara manual dengan menggunakan peralatan sederhanasehingga kurang efisien dikarenakan waktu produksi yang lama. Tujuan dari penelitian ini adalah merancang desain mesin penghancur daging bandeng sesuai keinginan UKM otak-otak Bandeng dengan menggunakan metode Quality Function Deployment (QFD). Data didapatkan dari kuesioner yang meliputi atribut spesifikasi mesin yang diinginkan oleh UKM berdasarkan nilai tingkat kepetingan tiap atribut dari mesin. Pengolahan data menggunakan uji validitas dan reliabilitas dengan software SPSS. Selain itu pengolahan dengan metode QFD yang dihitung berdasarkan tabel House Of Quality (HOQ). Hasil pengolahan didapatkan 10 atribut mesin otak-otak Bandeng yang sesuai kebutuhan UKM dan 9 atribut respon teknis yang dijadikan dasar untuk merancang desain mesin. Dari 10 atribut mesin yang sesuai kebutuhan pembeli tersebut didapatkan prioritas pertama atribut dari nilai contibution terbesar yaitu atribut tahan lama dengan nilai contibution sebesar 1,38 dan prioritas terakhir yaitu pada atribut kapasitas produksi meningkat dengan nilai 0,32. 


\section{Pendahuluan}

Sekor Usaha Kecil dan Menengah di Indonesia berdasarkan data yang ada tiap tahun mengalami perkembangan dalam hal jumlah. Berdasarkan data terakhir dari Badan Pusat Statistik pada tahun 2012 jumlah UMKM sebesar 55,2 juta, kemudian 2013 sebesar 56,5 juta, hingga 2014 sebanyak 57,8 juta. Dari data tersebut terlihat bahwa perkembangan UMKM rata-rata mencapai 1 juta per tahun[1]. Dampak dari perkembangan mengharuskan pemilik UKM untuk selalu meningkatkan kualitas produk yang baik agar mampu bersaing dengan pesaing serta mampu memproduksi produk lebih banyak.

Agar UKM menghasilkan produk dengan kualitas baik serta meningkatkan jumlah produkstivitasnya, maka pelaku UKM perlu menggunakan suatu teknologi mesin dalam proses produksinya. Sebab untuk saat ini perkembangan yang semakin pesat terkait teknologi mesin dengan sistem otomatisasi dan terkomputerisasi untuk proses produksi yang cepat dengan kualitas hasil produk juga baik[2].

Gresik adalah salah satu kota industri, namun di kota tersebut memiliki hasil pertanian seperti ikan bandeng yang dihasilkan oleh petani tambak. Dengan banyaknya ikan bandeng di daerah Gresik menyebabkan banyak pelaku UKM memproduksi produk oleh-oleh seperti otak-otak bandeng. Dengan banyak UKM yang membuat otak-otak bandeng sehingga produk tersebut menjadi salah satu oleh-oleh khas Gresik. Sehingga tidak mengherankan jika permintaan produk otak-otak bandeng semakin tahun semakin meningkat.

Namun, saat ini banyak UKM otak-otak Bandeng di Gresik tidak mampu memenuhi permintaan yang tinggi dan belum mampu meningkatkan kualitas produk lebih baik. Hal tersebut disebabkan karena masih banyaknya pelaku UKM menggunakan peralatan yang sederhana dan dibuat secara manual dengan tangan tanpa ada sentuhan Teknologi Tepat Guna (TTG). Tanpa adanya setuhan TTG yang berupa mesin mengakibatkan waktu proses produksi cukup lama sehingga kurang efektif dan efisien dalam menghancurkan daging bandeng.

Kemudian selain itu apabila pesanan otakotak bandeng cukup banyak dan melebihi kapasitas produksi per hari, maka pemilik UKM melemburkan atau menambah jam kerja karyawan. Tentunya hal tersebut akan berpengaruh terhadap peningkatan biaya Tenaga kerja. Maka dari itu untuk mengatasi masalah tersebut perlu adanya alat produksi yang dapat mempercepat proses untuk meningkatkan produktivitas serta kualitas produk otak-otak bandeng.

Perancangan alat produksi seperti mesin tentunya perlu mempertimbangkan aspek keinginan pengguna dalam hal ini yaitu pelaku UKM. Hal tersebut disebabkan karena pelaku UKM sebagai pengguna yang rata-rata belum terbiasa menggunakan mesin dalam proses produksinya. Apabila mesin yang rancang untuk digunakan ternyata kurang nyaman, maka akan menyebabkan pelaku UKM dapat menghentikan penggunaan mesin dan kembali memproduksi produk secara manual tanpa mesin seperti sebelumnya.

Berdasarkan penelitian sebelumnya terkait rancangan suatu mesin dengan metode berdasarkan pendapat atau keinginan dari pelanggan yiatu pada penelitian [3] tentang perancangan alat cetak isi resoles dengan metode QFD (Quality Fuction Deployment) untuk meningkatkan efisiensi dan efektifitas pada home industry roti.Berdasarkan dari penelitian tersebut menjelaskan bahwa dengan adanya penerapan TTG yang berupa mesin ternyata menghasilkan peningkatan produktivitas yang disertai dengan kualitas roti yang lebih baik dari sebelumnya. Namun dalam penelitian tersebut atribut yang ditentukan kurang banyak sehingga atribut produk berdasarkan keinginan konsumen kurang bervariatif. Kemudian pada penelitian[4] tentang penerapan metode QFD (Quality Fuction Deployment) untuk desain mesin penggilingan ikan. Pada penelitian tersebut menerapkan TTG yang berupa mesin 
untuk petani ikan pada proses penggilingan ternyata terjadi peningkatan produksi dari pada sebelumnya yang pada prosesnya tidak menggunakan mesin. Penelitian ini menghasilkan penggilingan yang mampu meningkatkan jumlah produksi. Namun pada penelitian tersebut atribut yang dihasilkan dalam merancang produk kurang banyak sehingga gambaran keinginan konsumen kurang bervariatif.

Sedangkan Pada [5] dalam penelitiannya tentang perancangan mesin pengupas buah pinang berbasiskan metode Quality Function Deployment(QFD). Pada penelitian tersebut peneliti merancang desain mesin untuk meningkatkan produktivitas pada proses mengupas buah pinang. Hasil dari penelitian menghasilkan desain mesin yang memiliki kemampuan meningkatkan produktivitas dari produksi sebelumnya yang menggunakan cara manual. Namun dalam penelitian ini jumlah atribut keinginan konsumen hanya 4 macam saja sehingga mengakibatkan spesifikasi mesin kurang banyak bervariasi.

Berdasarkan penelitian yang ada sebelumnya, bahwa peningkatan produktivitas suatu produk dan peningkatan kualitas produksi dibutuhkan suatu penerapan teknologi tepat guna seperti penggunaan mesin. Perancangan mesin perlu mempertimbangkan juga keinginan dari pengguna mesin sebab apabila tidak sesuai keingginan dari penggunan maka mesin tersebut akan sia-sia karena mesin tidak akan dipakai oleh penggunan. Maka dari itu dalam perancangan mesin dibutuhkan suatu metode yang berbasis kepada konsumen seperti metode Quality Function Deployment (QFD). Penelitian ini bertujuan untuk merancang suatu desain mesin penghancur bandeng untuk produksi otak-otak bandeng dengan metode Quality Function Deployment (QFD) untuk meningkatkan produktifitas dan meningkatkan kualitas produksi pada pelaku UKM Otak-otak Bandeng.

Rumusan masalah pada penelitian ini yaitu bagaimana merancang desain mesin penghancur bandeng untuk produksi otak-tak bandeng yang berguna meningkatkan produktifitas dan kualitas untuk UKM otakotak Bandeng. Sedangkan tujuan dari penelitian ini yaitu menghasilkan desain rancangan mesin produksi otak-otak Bandeng yang inovatif untuk meningkatkan produktivitas dan kualitas hasil produksi UKM otak-otak Bandeng.

\section{Metode Penelitian \\ 2.1 Pengembangan UMKM}

Pengembangan dapat diartikan sebagai suatu usaha untuk meningkatkan kemampuan konseptual, teoritis, teknis, dan moral individu sesuai dengan kebutuhan pekerjaan atau jabatan melalui pendidikan dan pelatihan. Menurut Afifuddin dalam[6]pengembangan UKM pada dasarnya lebih difokuskan menjadikan pelaku ekonomi mampu berdaya saing daripenguatan pada kewirausahaan serta meningkatan produktivitas yang dibantu pada upaya peningkatan penyesuaian kepada kebutuhan pasar, hingga memanfaatkan hasil inovasi serta penerapan teknologi. Pengaruh dari pengembangan UMKM di Indonesia dan melihat peran serta pemerintah dalam meningkatkan pertumbuhan UMKM di Indonesia memiliki hasil positif, baik secara langsung maupun tidak langsung [7].

\subsection{Desain Produk}

Desain biasa diterjemahkan sebagai seni terapan, arsitektur, dan berbagai pencapaian kreatif lainnya. Dalam sebuah kalimat, kata "desain" bisa digunakan baik sebagai kata benda maupun kata kerja. Sebagai kata kerja, "desain" memiliki arti "proses untuk membuat dan menciptakan obyek baru". Sebagai kata benda, "desain" digunakan untuk menyebut hasil akhir dari sebuah proses kreatif, baik itu berwujud sebuah rencana, proposal, atau berbentuk obyek nyata. Prosesdesain pada umumnya memperhitungkan aspek fungsi, estetik dan berbagai macam aspek lainnya, yang biasanya datanya didapatkan dari riset, pemikiran, brainstorming, maupun dari desain yang sudah ada sebelumnya. Akhir-akhir ini, proses (secara umum) juga dianggap sebagai 
produk dari desain, sehingga muncul istilah "perancangan proses" [8].

\subsection{Pengembangan Produk}

Menurut [9], "pengembangan produk adalah proses pencarian gagasan untuk barang dan jasa baru dan mengkonversikannya kedalam tambahan lini produk yang berhasil secara komersial". Pencarian produk baru didasarkan pada asumsi bahwa para pelanggan menginginkan unsur-unsur baru dan pengenaan produk baru akan membantu mencapai tujuan perusahaan [9].

Pengembangan produk ini sendiri bukanlah hal yang mudah, karena dalam pengembangan produk itu sendiri terdapat banyak hambatan baik itu dari dalam perusahaan ataupun dari luar perusahaan. Tidak sedikit perusahaan yang mengalami kegagalan dalam mengembangan produknya yang disebabkan karena perusahaan tersebut tidak dapat memecahkan hambatanhambatan itu [10].

\subsection{Quality Function Deployment (QFD)}

QFD (Quality Function Deployment) merupakan satu set alat untuk mengetahui prioritas kebutuhan pelanggan dengan cara subyektif ke dalam suatu set pada tingkat sistem selama dalam proses konseptual sistem desain untuk meningkatkan perencanaan produk[11]. QFD digunakan untuk memastikan bahwa perusahaan berusaha memusatkan perhatiannya terhadap kebutuhan konsumen sebelum setiap perancangan pekerjaan dilakukan [12]. QFD menggunakan House of Quality / HOQ (Rumah Kualitas) untuk menunjukkan hubungan antara beberapa kebutuhan konsumen yang ditranslasikan menjadi atribut-atribut teknis. HOQ merupakan gabungan dari matriks yang saling berhubungan satu dengan yang lainnya [13].

Tindakan-tindakan yang dilakukan dalam Quality Function Deployment (QFD) meliputi 4 proses/fase utama menurut Gaspersz dalam [14]yaitu product planning, design planning, process planning, dan production planning. Proses-proses tersebut merupakan suatu susunan proses yang terstruktur dan sistematis, yang memudahkan teknisi untuk mewujudkan keinginan konsumen dengan tepat menuju proses perancangan produk. Setiap fase memiliki matriks yang terdiri dari kolom vertikal yang berisi Whats dan baris horisontal yang berisi Hows. Whats adalah kebutuhan konsumen dan Hows adalah cara untuk mencapainya.

Menurut Ginting [15] manfaat-manfaat utama QFD adalah sebagai berikut:

a. Memusatkan rancangan produk dan jasa baru pada kebutuhan pelanggan.

b. Mengutamakan kegiatan-kegiatan desain.

c. Menganalisis kinerja produk perusahaan yang utama untuk memenuhi kebutuhan pelanggan.

d. Dengan berfokus pada upaya rancangan

e. Mengurangi banyaknya perubahan desain

f. Mendorong terselenggarakannya tim kerja dan menghancurkan rintangan antar bagian dengan melibatkan pemasaran, rekayasa teknik, dan pabrikasi seja awal proyek

g. Menyediakan suatu cara untuk membuat proses dan menyediakan suatu dsar yang kukuh untuk mengambil keputusan rancangan.

Dalam QFD menggunakan suatu matriks yang disebut house of quality, di mana matriks ini menterjemahkan keinginan konsumen ke dalam karasteristik desain.

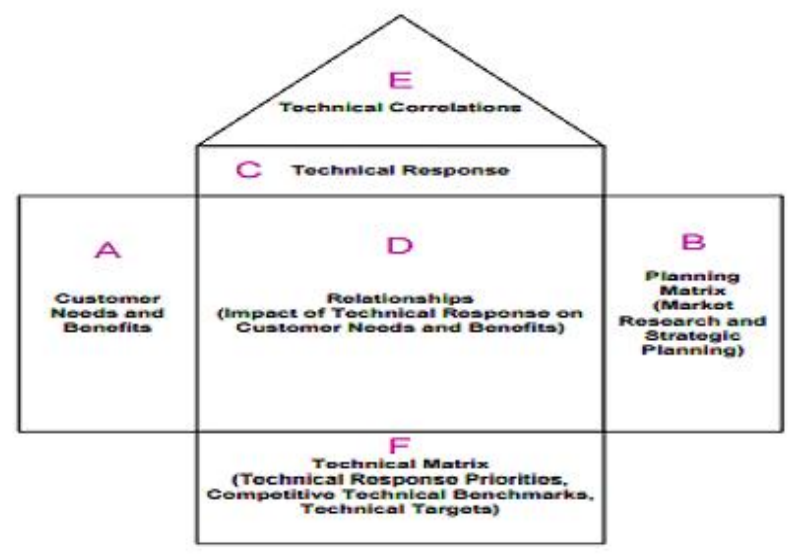

Gambar 1. House of Quality [13].

Pada Penelitian ini menggunakan beberapa narasumber yang semuanya adalah pemilik UKM Otak-otak Bandeng di Kelurahan Lumpur Kabupaten Gresik. Adapun data yang digunakan dalam penelitian ini 
terdiri dari 2 jenis data yaitu data kualitatif dan data kuantitatif. Data kualitatif yaitu data yang didadaptkan dari hasil wawancara untuk mendapatkan beberapa atribut dari mesin otakotak yang yang diingikan. Sedangkan untuk data kuantitatif yaitu data yang diambil secara langsung dengan bantuan kuesioner. Adapun data kuantitatif meliputi data tingkat kepentingan dari tiap atribut dengan menggunakan skala likert 1-4 dengan 20 orang sebagai narasumber. Setelah didapatkan data kualitatif maupun data kuantitatif kemudian dilakukan perhitungan uji validitas dan reliabilitas dengan bantuan software SPSS. Setelah itu dilakukan perhitungan tingkat kepentingan tiap atribut dari mesin yang akan dirancang. Setelah melakukan identifikasi respon teknis dari mesin tersebut yang didapatkan dari wawancara dengan narasumber dan juga data dari beberapa jurnal terkait topik penelitian ini. Kemudian menyusun House of Quality (HOQ) dengan menghubungkan keterkaitan antara beberapa atribut mesin dengan beberapa respon teknis.

\section{Hasil dan Pembahasan}

\subsection{Atribut Kebutuhan Konsumen}

Dari wawancara yang telah didapatkan dari 20 orang pelaku UKM otak-otak bandeng diperoleh atribut kebutuhan konsumen sebanyak 10 atribut. Adapun hasil rekapitulasi 10 atribut terdapat pada tabel berikut:

Tabel 1. Atribut Kebutuhan Konsumen

\begin{tabular}{ll}
\hline No & Atribut Kebutuhan Konsumen \\
\hline 1 & Tahan lama \\
\hline 2 & Mudah dibersihkan \\
\hline 3 & Mudah digunakan/ di operasikan \\
\hline 4 & Harga terjangkau \\
\hline 5 & Waktu proses cepat \\
\hline 6 & Hasil lebih halus dan higienis \\
\hline 8 & Kapasitas produksi meningkat \\
\hline 9 & Perawatan mesin mudah \\
\hline 10 & Saluah dipindahkan keluar besar \\
\hline
\end{tabular}

Sumber : Hasil olah Data

Berdasarkan tabel 1, maka 10 atribut tersebut digunakan untuk mendapatkan tingkat kepentingan dari tiap atribut kebutuhan konsumen tersebut. Tingkat kepentingan didapatkan dari hasil pengisian kuesioner dengan skala Likert skala 1-4 pada 20 orang narasumber. Adapun hasil rekapitulasi kuesioner tingkat kepentingan atribut kebutuhan konsumen terdapat pada tabel 2 berikut ini.

Tabel 2. Tingkat Kepentingan Atribut Kebutuhan Konsumen

\begin{tabular}{|c|c|c|c|c|c|}
\hline No & \begin{tabular}{|c|}
\multicolumn{1}{c}{ Atribut } \\
Kebutuhan \\
Konsumen
\end{tabular} & $\begin{array}{c}\text { TP } \\
\text { Skor } 1 \\
\text { (orang) }\end{array}$ & $\begin{array}{c}\text { CP } \\
\text { Skor } 2 \\
\text { (orang) }\end{array}$ & \begin{tabular}{|c|} 
P \\
Skor 3 \\
(orang)
\end{tabular} & $\begin{array}{c}\text { SPS } \\
\text { Skor } 4 \\
\text { (orang) }\end{array}$ \\
\hline 1 & $\begin{array}{l}\text { Tahan } \\
\text { lama }\end{array}$ & 1 & 2 & 5 & 12 \\
\hline 2 & $\begin{array}{l}\text { Mudah } \\
\text { dibersihkan }\end{array}$ & 2 & 7 & 2 & 9 \\
\hline 3 & $\begin{array}{l}\text { Mudah } \\
\text { digunakan/ } \\
\text { di } \\
\text { operasikan }\end{array}$ & 3 & 0 & 9 & 8 \\
\hline 4 & $\begin{array}{l}\text { Harga } \\
\text { terjangkau }\end{array}$ & 1 & 1 & 4 & 14 \\
\hline 5 & $\begin{array}{l}\text { Waktu } \\
\text { proses } \\
\text { cepat }\end{array}$ & 1 & 6 & 3 & 10 \\
\hline 6 & $\begin{array}{l}\text { Hasil lebih } \\
\text { halus dan } \\
\text { higienis }\end{array}$ & 1 & 2 & 3 & 14 \\
\hline 7 & $\begin{array}{l}\text { Kapasitas } \\
\text { produksi } \\
\text { meningkat }\end{array}$ & 2 & 2 & 4 & 12 \\
\hline 8 & $\begin{array}{l}\text { Perawatan } \\
\text { mesin } \\
\text { mudah }\end{array}$ & 1 & 8 & 5 & 6 \\
\hline 9 & $\begin{array}{l}\text { Mudah } \\
\text { dipindahkan }\end{array}$ & 2 & 2 & 7 & 9 \\
\hline 10 & $\begin{array}{l}\text { Saluran } \\
\text { keluar } \\
\text { besar }\end{array}$ & 1 & 4 & 6 & 9 \\
\hline
\end{tabular}

Keterangan :

TP (Tidak Penting) skor 1, CP (Cukup Penting) skor 2, P (Penting) skor 3, SPS (Sangat Penting Sekali) Skor 4.

\subsection{Uji Validitas dan Reliabilitas}

Berdasarkan hasil tingkat kepentingan yang telah didapatkan pada Tabel 2, maka data tersebut dilakukan uji validitas dan reliabilitas dengan bantuan software SPSS untuk mengetahui apakah hasil kuesioner telah valid dan juga dinyatakan reliabel. Adapun hasil uji validitas dan reliabilitas terdapat pada tabel 3 dan tabel 4. 
Tabel 3. Hasil Uji Validitas

\begin{tabular}{lllll}
\hline $\begin{array}{l}\text { Kode } \\
\text { Atribut }\end{array}$ & $\begin{array}{l}\text { Nilai R } \\
\text { Hitung }\end{array}$ & $\begin{array}{l}\text { Nilai } \\
\mathbf{R} \\
\text { Tabel }\end{array}$ & $\begin{array}{l}\text { Nilai } \\
\text { Sig. }\end{array}$ & $\begin{array}{l}\text { Keput } \\
\text { usan }\end{array}$ \\
\hline X1 & 0,575 & 0,444 & 0,008 & Valid \\
\hline X2 & 0,718 & 0,444 & 0,000 & Valid \\
\hline X3 & 0,709 & 0,444 & 0,000 & Valid \\
\hline X4 & 0,773 & 0,444 & 0,000 & Valid \\
\hline X5 & 0,693 & 0,444 & 0,001 & Valid \\
\hline X6 & 0,627 & 0,444 & 0,003 & Valid \\
\hline X7 & 0,743 & 0,444 & 0,000 & Valid \\
\hline X8 & 0,697 & 0,444 & 0,003 & Valid \\
\hline X10 & 0,815 & 0,444 & 0,000 & Valid \\
\hline
\end{tabular}

Sumber : Hasil olah Data

Dari hasil tabel 3 mulai X1 hingga X10 memiliki nilai Rhitung > R Tabel (RHitung lebih besar dari RTabel) menunjukkan bahwa data yang didapat dari hasil kuesioner dinyatakan "Valid".

Berdasarkan tabel 3, dimana nilai Rhitung > dari RTabel menunjukkan bahwa kuesioner tersebut "Valid" atau Nilai Sig. tidak lebih besar dari 5\% juga menunjukkan bahwa kuesioner tersebut "valid".

Tabel 4. Hasil Uji Reliabilitas

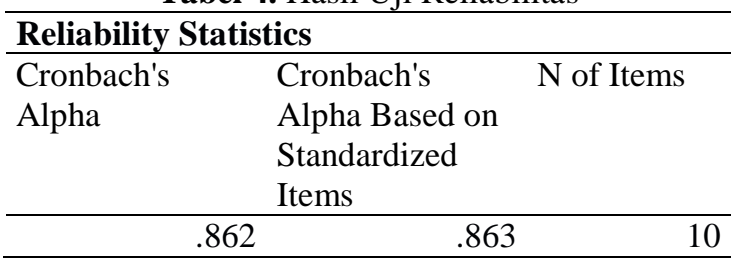

Sumber : Hasil olah Data

Dari hasil perhitungan dengan SPSS ternyata menghasilkan nilai Cronbach alphasebesar $86 \%$ dimana nilai tersebut lebih besar dari $60 \%$. Sehingga dinyatakan bahwa nilai tingkat kepentingan pada atribut kebutuhan konsumen dinyatakan "Reliabel".

\subsection{Nilai Tingkat Keepentingan Pada Atribut Mesin}

Berdasarkan hasil uji validitas dan uji reliabilitas tersebut, maka dilakukan perhitungan nilai kepentingan konsumen terhadap atribut nilai kebutuhan mesin pengahancur daging bandeng. Pada Perhitungan ini data yang digunakan yaitu data rekapitulasi kuesioner kepentingan atribut kebutuhan konsumen dengan skala liker 1-4 yang diberikan pada 20 orang narasumber.
Tabel 5. Nilai Tingkat Kepentingan Atribut Mesin

\begin{tabular}{lllc}
\hline No & $\begin{array}{l}\text { Atribut } \\
\text { Kebutuhan } \\
\text { konsumen }\end{array}$ & $\begin{array}{l}\text { Tot } \\
\text { al }\end{array}$ & $\begin{array}{l}\text { Tingkat } \\
\text { Kepentingan }\end{array}$ \\
\hline 1 & Tahan lama & 68 & 3,4 \\
\hline 2 & Mudah dibersihkan & 58 & 2,9 \\
\hline 3 & $\begin{array}{l}\text { Mudah digunakan/ } \\
\text { di operasikan }\end{array}$ & 62 & 3,1 \\
\hline 4 & Harga terjangkau & 71 & 3,6 \\
\hline 5 & Waktu proses cepat & 62 & 3,1 \\
\hline 6 & $\begin{array}{l}\text { Hasil lebih halus } \\
\text { dan higienis }\end{array}$ & 70 & 3,5 \\
\hline 7 & $\begin{array}{l}\text { Kapasitas produksi } \\
\text { meningkat }\end{array}$ & 66 & 3,3 \\
\hline 8 & $\begin{array}{l}\text { Perawatan mesin } \\
\text { mudah }\end{array}$ & 56 & 2,8 \\
\hline 9 & $\begin{array}{l}\text { Mudah } \\
\text { dipindahkan }\end{array}$ & 63 & 3,2 \\
\hline 10 & $\begin{array}{l}\text { Saluran keluar } \\
\text { besar }\end{array}$ & 63 & 3,2 \\
\hline
\end{tabular}

Sumber : Hasil olah Data

Keterangan :

Nilai total yaitu total skor Likert 1-4 yang diberikan pada tiap atribut dari hasil kuesioner. Sehingga pada nilai total didapatkan dari penjumlahan skor penilaian dari semua narasumber yang berjumlah 20 orang. Sedangkan untuk mendapatkan nilai tingkat kepentingan yaitu nilai total skor tiap atribut kebutuhan konsumen dibagi dengan jumlah responden atau narasumber sebanyak 20 orang. Perhitungan tingkat kepentingan pada atribut kebutuhan konsumen pada no 1 yaitu total skor $68 / 20=3,4$. Kemudian untuk atribut kebutuhan konsumen pada no. 3 hingga no. 10 di huting dengan cara yang sama yaitu nilai total skor dibagi dengan jumlah narasumber sebanyak 20 orang menghasilakan nilai tingkat kepentingan yang tertera pada tabel 5 .

\subsection{Penentuan Respon Teknis}

Setelah dilakukan perhitungan pada tabel 5, maka selanjutnya dilakukan penentuan respon teknis dari alat atau mesin yang akan dibuat. Dalam penentuan atribut respon teknis dilakukan dengan cara wawancara dengan pembuat mesin dan juga didapatkan dari beberapa jurnal terkait tentang perancangan mesin. Respon teknis didentifikasi untuk tujuan menterjemahkan atribut kebutuhan konsumen terhadap mesin yang akan dibuat. 
Tabel 6. Respon Teknis

\begin{tabular}{ll}
\hline No & Respon Teknis \\
\hline 1 & Kualitas bahan kuat \\
\hline 2 & Kualitas bahan ringan \\
\hline 3 & Desain bentuk \& ukuran \\
\hline 4 & Pisau potong tajam \\
\hline 5 & Diameter saluran keluar \\
\hline 6 & Ukuran bak cukup besar \\
\hline 7 & Sparepart mudah didapatkan \\
\hline 9 & Sistem pengaturan kecepatan \\
\hline
\end{tabular}

Sumber : Hasil Olah Data

\subsection{Pembuatan House of Quality}

Setelah didapatkan data atribut respon teknis, maka selanjutnya membuat House of Quality (HOQ) berdasarkan hasil olah data yang telah didapatkan sebelumnya. Untuk membuat gambar dan perhitungan HOQ dibutuhkan beberapa analisa yaitu :

1. Menentukan keterkaitan antara antribut kebutuhan konsumen dan respon teknis.

Analisa hubungan keterkaitan antara atribut kebutuhan konsumen dan respon teknis dalam HOQ dinyatakan dalam beberapa simbol sebagai berikut :

a. Hubungan kuat $\boldsymbol{Q}$, bobot keterhubungan $=9$

b. Hubungan sedang ( $\mathrm{O}$ ), bobot keterhubungan $=3$

c. Hubungan lemah $(\Delta)$, bobot keterhubungan $=1$

2. Menentukan hubungan antar sesamaatribut respon teknis.

Menentukan hubungan antar sesama respon teknis untuk mengetahui apakah tiap atribut respon teknis memiliki hubungan yang kuat, positif, none, atau negative. Hubungan keterkaitan tersebut dalam HOQ disimbolkan sebagai berikut :

\begin{tabular}{|c|c|}
\hline \multicolumn{2}{|c|}{ Correlation } \\
\hline Strong + & \\
\hline Positive & $\bigcirc$ \\
\hline None & \\
\hline Negative & \\
\hline Strong - & \\
\hline
\end{tabular}

Gambar 2. Simbol hubungan antar respon teknis
3. Sales Point

Menentukan Sales pointdimaksudkan untuk mengetahui nilai jual tinggi pada atribut produk yang akan dirancang. Nilai sales point terdiri dari :

1 = Tidak ada sales point

$1,2=$ Sales point sedang

$1,5=$ Sales point $\mathrm{kuat}$

\section{Target / Goal}

Tahap selanjutnya yaitu menentukan nilai target atau goal adalah adalah suatu nilai yang ingin diperoleh dalam proses merancang produk yang sesuai dengan kebutuhan yang diinginkan oleh konsumen. Nilai target dapat didasarkan pada nilai atau skala likert 1-4 sesuai skala pertanyaan di kuesioner tentang atribut produk yang sesuai kebutuhan konsumen.

5. Nilai improvement ratio

Improvement ratio adalah nilai rasio yang dihasilkan untuk mengetahui seberapa besar perubahan ataupun perbaikan yang perlu dilakukan terhadap atribut dari produk yang akan di rancang atau diciptakan. Perhitungan nilai improvement ratio terdapat pada tabel 7 di bawah ini.

Tabel 7. Improvement Ratio (I.R)

\begin{tabular}{|c|c|c|c|c|}
\hline No & $\begin{array}{l}\text { Atribut } \\
\text { Kebutuhan } \\
\text { konsumen }\end{array}$ & Goal & $\begin{array}{l}\text { Tingkat } \\
\text { Kepenti } \\
\text { ngan }\end{array}$ & I.R \\
\hline 1 & Tahan lama & 4 & 3,4 & 1,18 \\
\hline 2 & $\begin{array}{l}\text { Mudah } \\
\text { dibersihkan }\end{array}$ & 4 & 2,9 & 1,38 \\
\hline 3 & $\begin{array}{l}\text { Mudah } \\
\text { digunakan/ di } \\
\text { operasikan }\end{array}$ & 4 & 3,1 & 1,29 \\
\hline 4 & $\begin{array}{l}\text { Harga } \\
\text { terjangkau }\end{array}$ & 4 & 3,6 & 1,13 \\
\hline 5 & $\begin{array}{l}\text { Waktu proses } \\
\text { cepat }\end{array}$ & 4 & 3,1 & 1,29 \\
\hline 6 & $\begin{array}{l}\text { Hasil lebih } \\
\text { halus dan } \\
\text { higienis }\end{array}$ & 4 & 3,5 & 1,14 \\
\hline 7 & $\begin{array}{l}\text { Kapasitas } \\
\text { produksi } \\
\text { meningkat }\end{array}$ & 4 & 3,3 & 1,21 \\
\hline 8 & $\begin{array}{l}\text { Perawatan } \\
\text { mesin mudah }\end{array}$ & 4 & 2,8 & 1,43 \\
\hline 9 & $\begin{array}{l}\text { Mudah } \\
\text { dipindahkan }\end{array}$ & 4 & 3,2 & 1,27 \\
\hline
\end{tabular}




\begin{tabular}{lllll}
\hline 10 & $\begin{array}{l}\text { Saluran keluar } \\
\text { besar }\end{array}$ & 4 & 3,2 & 1,27 \\
\hline
\end{tabular}

Keterangan :

Nilai Improvement ratio di dapat dari hasil nilai Goal dibagi dengan nilai tingkat kepentingan. Contoh : 4/3,4 =1,18.

6. Raw Weight dan Normalized Raw Weight Raw weight dan normalized raw weight merupakan perhitungan yang dilakukan untuk mengetahui besarnya perubahan ataupun perbaikan yang akan dilakukan terhadap atribut kebutuhan konsumen terhadap produk yang akan di buat. Adapun hasil raw weight dan normalized raw weight sebagai berikut :

Tabel 8. Raw Weight dan Normalized Raw

\begin{tabular}{llccc}
\multicolumn{5}{c}{ Weight } \\
\hline $\begin{array}{l}\text { N } \\
\text { o }\end{array}$ & $\begin{array}{l}\text { Atribut } \\
\text { Kebutuhan } \\
\text { konsumen }\end{array}$ & $\begin{array}{c}\text { Sales } \\
\text { point }\end{array}$ & $\begin{array}{c}\text { Raw } \\
\text { Weight }\end{array}$ & $\begin{array}{l}\text { Normaliz } \\
\text { ed Raw } \\
\text { Weight }\end{array}$ \\
\hline 1 & Tahan lama & 1,5 & 6,0 & 0,11 \\
\hline 2 & $\begin{array}{l}\text { Mudah } \\
\text { dibersihkan }\end{array}$ & 1,2 & 4,8 & 0,09 \\
\hline 3 & $\begin{array}{l}\text { Mudah } \\
\text { digunakan/ di } \\
\text { operasikan }\end{array}$ & 1,5 & 6,0 & 0,11 \\
\hline 4 & $\begin{array}{l}\text { Harga } \\
\text { terjangkau }\end{array}$ & 1,5 & 6,0 & 0,11 \\
\hline 5 & $\begin{array}{l}\text { Waktu proses } \\
\text { cepat }\end{array}$ & 1,5 & 6,0 & 0,11 \\
\hline 6 & $\begin{array}{l}\text { Hasil lebih } \\
\text { halus dan } \\
\text { higienis }\end{array}$ & 1,5 & 6,0 & 0,11 \\
\hline 7 & $\begin{array}{l}\text { Kapasitas } \\
\text { produksi } \\
\text { meningkat }\end{array}$ & 1,5 & 6,0 & 0,11 \\
\hline 8 & $\begin{array}{l}\text { Perawatan } \\
\text { mesin mudah }\end{array}$ & 1,5 & 6,0 & 0,11 \\
\hline 9 & $\begin{array}{l}\text { Mudah } \\
\text { dipindahkan }\end{array}$ & 1,2 & 4,8 & 0,09 \\
\hline 1 & $\begin{array}{l}\text { Saluran keluar } \\
\text { besar }\end{array}$ & 1,2 & 4,8 & 0,09 \\
\hline Total & $\mathbf{5 6 , 4}$ & \\
\hline Ketangan : & & & \\
\hline
\end{tabular}

Keterangan :

- Nilai Raw Weight didapatkan dari nilai tingkat kepentingan $\mathrm{x}$ improvement ratio $\mathrm{x}$ sales point. Contoh: $3,4 \times 1,18 \times 1,5=6$.

- Nilai normalized raw weight didapatkan dari nilai raw weight dibagi dengan nilai total raw weight. Contoh : $6 / 56,4=0,11$.

7. Contribution

Nilai Contribution dimaksudkan untuk mengetahui peringkat dari tiap atribut kebutuhan konsumen. Perhitungan nilai contribution didapatkan dari hasil nilai keterkaitan antara atribut kebutuhan konsumen dengan respon teknis dikalikan nilai normalized raw weight. Adapun nilai contribution sebagai berikut.

Tabel 9. Nilai Contribution

\begin{tabular}{llc}
\hline No & $\begin{array}{l}\text { Atribut Kebutuhan } \\
\text { konsumen }\end{array}$ & $\begin{array}{c}\text { Contrib } \\
\text { ution }\end{array}$ \\
\hline 1 & Tahan lama & 1,38 \\
\hline 2 & Mudah dibersihkan & 1,11 \\
\hline 3 & $\begin{array}{l}\text { Mudah digunakan/ } \\
\text { dioperasikan }\end{array}$ & 1,28 \\
\hline 4 & Harga terjangkau & 0,96 \\
\hline 5 & Waktu proses cepat & 1,17 \\
\hline 6 & Hasil lebih halus dan higienis & 0,96 \\
\hline 7 & Kapasitas produksi meningkat & 0,32 \\
\hline 8 & Perawatan mesin mudah & 0,96 \\
\hline 9 & Mudah dipindahkan & 1,02 \\
\hline 10 & Saluran keluar besar & 0,77 \\
\hline
\end{tabular}

Sumber : Hasil olah Data

Dari hasil perhitungan yang dilakukan sebelumnya, maka dapat dibuatkan House of Quality (HOQ) dari metode Quality Function Deployment(QFD) berikut ini.

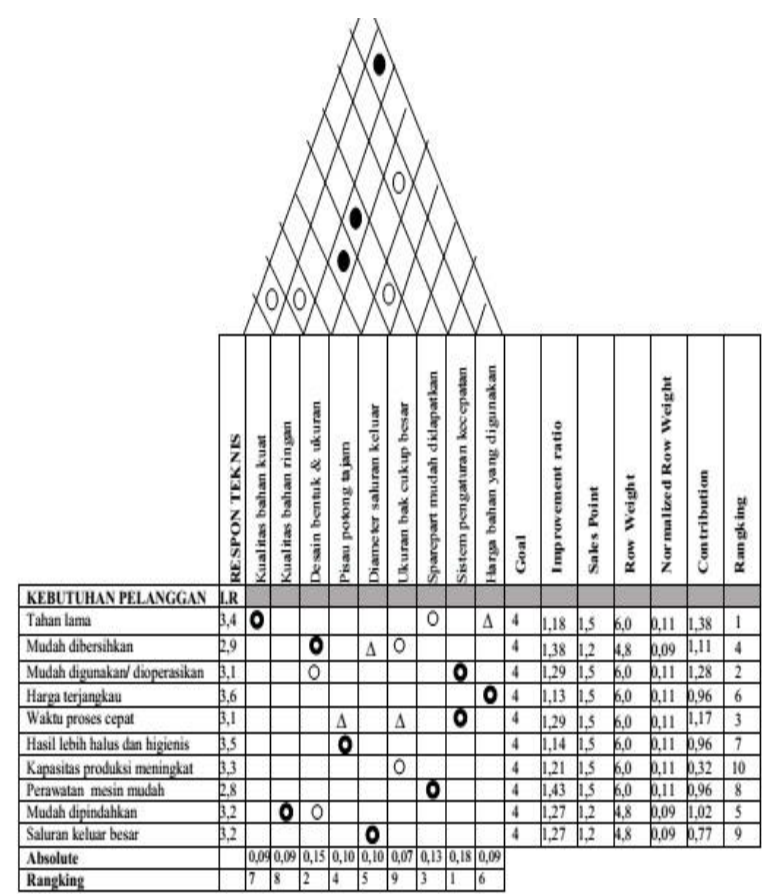

Gambar 3. HasilHouse of Quality (HOQ)

\subsection{Desain Mesin berdasarkan Hasil QFD}

Berdasarkan pengolahan data dengan QFD yang telah dilakukan, maka dibuatkan desain desain penghancur ikan bandeng untuk produksi otak-otak bandeng dengan 
mempertimbangkan atribut kebutuhan konsumen dan respon teknis yang telah didapatkan dari hasil pengolahan QFD. Adapun desain mesin penghancur bandeng sebagai berikut:

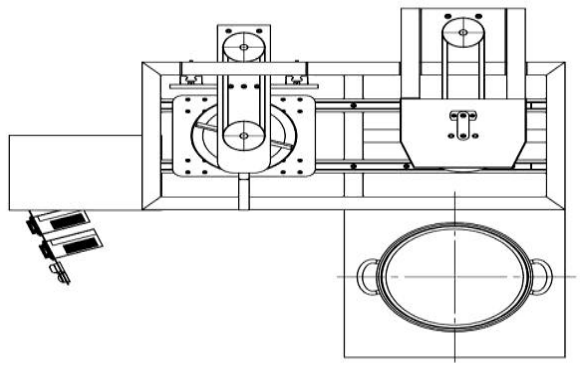

Gambar 4. Desain Mesin Tampak Atas

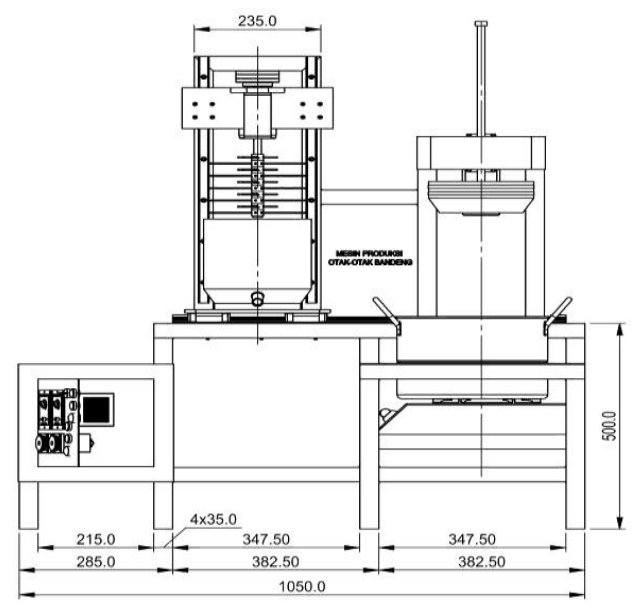

Gambar 5. Desain Mesin Tampak Depan

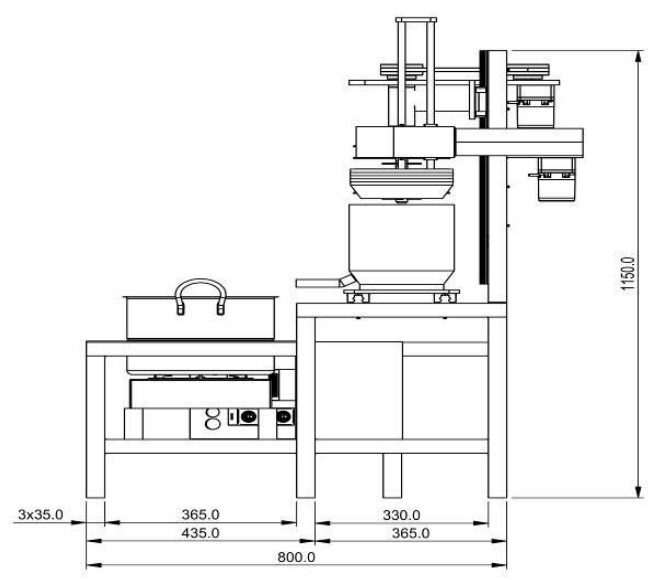

Gambar 6. Desain Mesin Tampak Samping

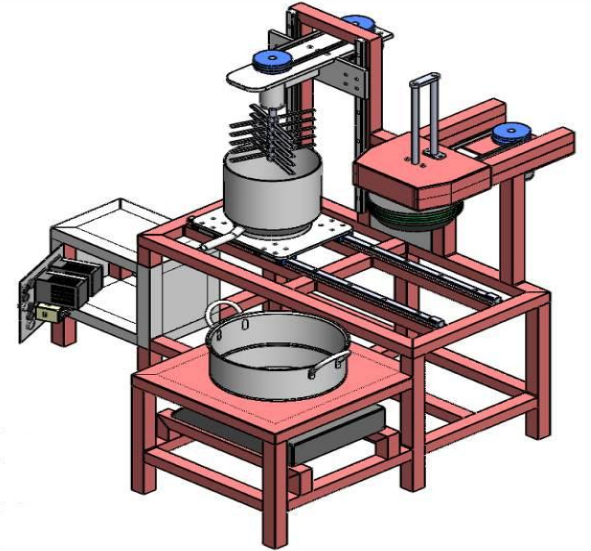

Gambar 7. Desain mesin tampak 3D

\section{Kesimpulan dan Saran}

Berdasarkan pengolahan dan analisa hasil dari penelitian, maka dapat ditarik kesimpulan bahwa perancangan desain mesin otak-otak Bandeng dengan metode Quality Function Deployment (QFD) menghasilkan 10 atribut mesin yang sesuai keinginan dari pembeli atau pengguna mesin dalam hal ini pelaku UKM otak-otak bandeng dan juga menghasilkan 9 atribut respon teknis yang sesuai dengan kebutuhan pembeli atau pengguna mesin. Sedangkan untuk atribut mesin yang paling diprioritaskan dari hasil penelitian dengan perhitungan nilai contribution yang terbesar hingga yang terkecil yaitu atribut mesin yang tahan lama dengan nilai contribution sebesar 1,38dan untuk atribut yang mendapat prioritas terakhir yaitu pada atribut kapasitas produksi meningkat dengan nilai contribution sebesar 0,32 .

Sehingga pada mesin ini mengalami pengembangan dari yang awalnya pembuatan oak-oatak bandeng dilakukan secara manual, sekarang pelaku UKM otak-otak bandeng dapat membuat produk dengan mesin yang otomatis dengan proses produksi yang lebih cepat, kualitas penggilingan ikan lebih halus, dan hasil lebih higienis.

Saran yang dapat diberikan pada penelitian ini yaitu perlunya dilakukan suatu identifikasi yang lebih banyak dari pendapat UKM otak-otak. Sebab dengan mengidentifikasi kepada banyak UKM maka dapat diperoleh atribut yang lebih banyak. Apabila jumlah usulan atribut kebutuhan mesin dapat lebih banyak dan mesin yang akan dirancang tentunya memiliki fitur atau fungsi dari mesin yang lebih bervariasi sehingga 
pengembangan mesin produksi otak-otak bandeng selalu mengalami perkembangan.

\section{Daftar Pustaka}

[1] Badan Pusat Statistik. (2014, Januari 30). Tabel Perkembangan UMKM (19972013) [Online].Available: https//www.b ps.go.id/statictable/2014/01/30/1322/tab el-perkembangan-umkm-pada-periode1997--2013.html.

[2] Y. Pratiwi and Ismanto, "Peningkatan Kuantitas Dan Kualitas Produk Melalui Perbaikan Teknologi Proses Produksi Pada Usaha Kerajinan Batu Putih Gunung Kidul,"Jurnal Inoteks, vol. 15, no. 5, pp. $109-115,2011$.

[3] A. Permatadenyn and E.Nuryulianti, "Dengan Metode Quality Function Deployment (QFD) Untuk Meningkatkan Efisiensi Dan Efektivitas Pada Home Industry Roti," Jurnal Teknoscienza, Vol.1, No.1,pp. 1-14, 2016.

[4] A. Shobiruddin and D. Wulandari, "Penerapan Metode QFD ( Quality Function Deployment ) Untuk Desain Mesin Penggiling Pakan Ikan," Jurnal Rekayasa Mesin,vol. 4, no. 2, pp. 181189, 2017.

[5] A. Pranata, Yohanes, and Satriardi, "Perancangan Mesin Pengupas Buah Pinang Berbasiskan Metode Quality Function Deployment (QFD)," Jurnal Online Mahasiswa Fakultas Teknik Universitas Riau, vol. 3, no. 1, pp. 1-5, 2016.

[6] Alyas and M. Rakib, "Strategi Pengembangan Usaha Mikro, Kecil Dan Menengah Dalam Penguatan Ekonomi Kerakyatan (Studi Kasus pada Usaha Roti Maros di Kabupaten Maros)," Jurnal Sosiohumaniora, Vol. 19, No. 2, pp. 114 - 120, 2017.

[7] L. M. Hamzah and D. Agustien, "Pengaruh Perkembangan Usaha Mikro, Kecil, Dan Menengah Terhadap
Pendapatan Nasional Pada Sektor UMKM Di Indonesia," Jurnal Ekonomi Pembagunan,Vol. 8, No 2, pp. 215 228, 2019.

[8] P. Yuliarty, T. Permana, and A. Pratama, "Pengembangan desain produk papan tulis dengan metodeQuality Function Deployment (QFD)," Jurnal Ilmiah PASTI, vol. 4, no. 1, pp. 1-13, 2008.

[9] H. Simamora, Manajemn Pemasaran Internasional, Jilid II., Ed.2, Cetakan1, Jakarta: Rineka Cipta, 2007.

[10] M. Jannah, "Faktor-Faktor Yang Mempengaruhi Kegagalan Usaha,"Jurnal Islamiconomic, vol. 6, no. 1, pp. 25-42, 2015.

[11] N. I. Piri, A. Sutrisno, and J. Mende, "Penerapan Metode Quality Function Deployment (QFD) Untuk Menangani Non Value Added Activity Pada Proses Perawatan Mesin," Jurnal Online Poros Teknik Mesin, vol. 6, no. 1, pp. 10-19, 2017.

[12] R. Prabowo and M.I. Zoelangga, "Pengembangan Produk Power Charger Portable dengan Menggunakan Metode Quality Function Deployment ( QFD )," Jurnal Rekayasa Sistem Industri, vol. 8, no. 1, pp. 55-62. 2019.

[13] L. Cohen, Quality Function Deployment : How to Make QFD Work for You, Massachusetts: Addison-Wesley Publishing Company, 1995.

[14] E. Suhendar, "Penerapan Metode Quality Function Deployment (QFD) Dalam Upaya Peningkatan Kualitas Pelayanan akademik Pada UB," Jurnal Faktor Exacta, vol. 7, no. 4, pp. 372-386, 2014

[15] R. Ginting, Perancangan Produk,Edisi 1, Yogyakarta: Graha Ilmu, 2009. 